\title{
Performance Test of the Waste Water Ammonia Converter Device (AnCerD) for the Ammonia Removal in Shrimp Farm Industry
}

\author{
Karmanto \\ Chemistry Education Department, Faculty of Science and Technology, UIN Sunan Kalijaga \\ J1. Marsda Adisucipto No 1 Yogyakarta 55281, Indonesia. Tel. +62-274-540971, Fax. +62-274-519739 \\ Email: karmanto@uin-suka.ac.id or karmanto45@gmail.com
}

\begin{abstract}
In Indonesia, shrimp farm is one type of fishery industry that faces problems in relation to ammonia in its water cycle management, especially for PT Indokor Bangun Desa (PT IBD). The electrolysis way is one of the most potential methods for the shrimp farm's ammonia wastewater removal because it is a simple technology with the low-cost technical operation and no hazardous emission produced. The objective of this preliminary research was to design an ammonia converter device (AnCerD) that equipped by simple ammonia monitoring tools and tested its performance at laboratory scale. The performance testing had been done include: testing of analyzer compartment for ammonia rapid analysis and testing of converter compartment for ammonia conversion capability. Testing of the AnCerD instrument shown good performance, where no significant different result between analyzer compartment measurement and spectroscopic method of SNI 06-6989.30-2005 (P>0.05). Good performance was also shown by converter compartment testing result where the ammonia conversion efficiency achieved more than $95.64 \%$ after 16 minutes.
\end{abstract}

Keywords: Ammonia converter device, AnCerD, Electrolysis

\section{INTRODUCTION}

In Indonesia, shrimp farm is one type of fishery industry that faces problems in relation to ammonia in its water cycle management, especially for PT Indokor Bangun Desa (PT IBD). PT IBD is one of the company's environmentally friendly shrimp farm at Srandakan District, Bantul, Yogyakarta, Indonesia. A typical shrimp ponds wastewater at outlet canal of PT IBD can have a concentration of ammonia as high as $0,8 \mathrm{mg} / \mathrm{L}$. This value is well above the allowed concentration of ammonia in ponds water, which is about $0,1 \mathrm{mg} / \mathrm{L}$. The main sources of ammonia are from the shrimp excrement, food remains, planktons, and other organisms which die in the pond.

Several methods have been made to decrease the concentration of ammonia in the shrimp ponds wastewater. Among of them are bioremediation using nitrifying bacteria, zeolite adsorption techniques, stripping with ambient air, and ion exchange. However, these techniques are not as effective as they are very costly and need intensive maintenance (Riwayanti, 2010).

Nowadays, electrolysis technology in ammonia waste treatment is one of the methods that most attracted the attention of the researchers. Directly electrolysis of ammonia is able to reduce ammonia concentration of the water body significantly with low maintenance costs and simple technology. On the other hand conversion ammonia to gaseous nitrogen is environmentally friendly wastewater treatment which doesn't generate new waste (Liu et al, 2009).

Study on current parameter, electrolyte concentration, $\mathrm{pH}$, and type of electrode have been done for improving the efficiency of ammonia removal treatment. Various types of electrodes had been tested in ammonia decomposition study. Wang Y. et al (2012) had studied various cathode such as copper, zinc, titanium, and iron, with an objective to enhance the selectivity of ammonia to nitrogen gas and to remove the by-products in an undivided electrochemical cell, in which various cathodes and $\mathrm{Ti} / \mathrm{Ru} 02-\mathrm{Pt}$ anode were assembled. This research focuses on the influence of the electrolyte solution and kinds of the cathode materials on ammonia/ammonium removal in cell electrolysis.

On the basis of research studies above, the electrolysis way is one of the most potential methods for the shrimp farm's ammonia wastewater removal because it is a simple technology with low-cost technical operation and no hazardous emission produced. But technically, there is one problem remains that faced by shrimp farm management, the real-time water quality data, for fast decision making. So in this preliminary research, we try for designing an ammonia converter instrument (AnCerD) that equipped by simple ammonia monitoring tools and test its performance at laboratory scale.

\section{MATERIALS AND METHODS}

\section{Materials}

Ammonium chloride standard solution 100 ppm, sodium chloride rough crystal, sodium hydroxide 0.5 M. All of this material was purchased from chemic laboratory supplier Jogjakarta. 


\section{Procedures}

\section{Instrumentation Design}

Instrumentation used in this research was called AnCerD (ammonia Converter). This instrument was assembled by researcher and team of instrumentation, at Integrated Laboratory of UIN Sunan Kalijaga. The instrument of ammonia converter was designed in two compartments i.e., converter compartment and analyzer compartment. Converter compartment consists of electrolysis cell (equipped with carbon as anode and aluminum as cathode), direct current power supply, voltmeter, and Ampere meter. Wide of carbon surface area is $50.54912 \mathrm{~cm}^{2}$ while the aluminum is $41.8 \mathrm{~cm}^{2}$. The analyzer compartment consists of a series: ammonia gas sensor, power supply, microcontroller, and simple screen display. Sensitive material used as ammonia gas sensor is $\mathrm{SnO}_{2}$.

\section{Adjustment Test of the Instrument}

In this research, instrument adjustment test was done for each compartment i.e. analyzer compartment and converter compartment. The analyzer compartment was adjusted firstly for sensor training. This Process has to be done to make sure gasses sensor be able to read $\mathrm{NH}_{3}$ in certain concentration. The training process used $\mathrm{NHCl}$ standard solution prepared in 4 variation concentration i.e. $0.5 ; 3 ; 5$ and $20 \mathrm{mg} / \mathrm{l}$ respectively. Sensor will detect ammonia gas as voltage number which equals to the ammonia concentration detected. The correlation between voltage number and ammonium concentration then was graphed to obtained mathematical function for converting voltage number into equal ammonia concentration. Further adjustment test was converter compartment test. This test was done for instrument's capability testing on ammonia converting at variations of electrolysis time of trial sample. Trial samples used for this test were standard solution of $250 \mathrm{ml} \mathrm{NH} \mathrm{N}_{4} \mathrm{Cl} 100 \mathrm{ppm}$. Various selected time for the test was $10,12,14,16$, and 18 minutes respectively. Analog ammonia concentrations before and after treatment were measured by gasses sensor at analyzer compartment.

\section{Performance Test of the Instrument for Real Sample of PT IBD's Wastewater}

Performance tests of instrument for real sample carried out in two-stage i.e. comparative test, and ammonia conversion capability test. Real samples used for this test was sample taken from one of PT IBD's outlet canals. Comparative test was done by compare measurement result of analyzer compartment to the ammonia monitoring result of PT IBD. Ammonia conversion capability test of the instrument was carried out in five selected time of electrolysis in converter compartment. Various selected time for the test was 10 , $12,14,16$, and 18 minutes respectively for $250 \mathrm{ml}$ of sample. Analog ammonia concentrations before and after treatment were measured by gasses sensor at analyzer compartment. Result of analyzer compartment was compared to result of spectroscopic method of Indonesian National Standard (SNI 06-6989.30-2005).

\section{RESULTS AND DISCUSSION}

\section{Adjustment Test of Analyzer Compartment}

The analyzer compartment adjustment was carried out as a calibration procedure of analyzer compartment. This procedure was started by sensor training process. Sensitive sensor used in this research is $\mathrm{SnO} 2$ which with lower conductivity in clean air and higher along with the ammonia concentration rising. Basic concept using ammonia gas sensor for dissolved ammonia/ammonium measurement was inspired by Henry's Law constants for ammonia, where the physical process of ammonia transfer across a water surface in contact with the atmosphere is described by the simple reaction i.e.:

$$
\begin{aligned}
& \mathrm{NH}_{3}(\mathrm{~g}) \\
& \mathrm{NH}_{3}(\mathrm{aq}) \\
& +\mathrm{H}_{2} \mathrm{O}_{\text {(a) }} \leftarrow \rightarrow \mathrm{NH}_{4}{ }^{+}{ }_{\text {(aq) }}+\mathrm{OH}^{-}{ }_{\text {(aq) }}
\end{aligned}
$$

We use Henry's Law constant defined as:

$$
K_{H}=\frac{P_{a}}{C_{w}}
$$

Where $\mathrm{Pa}$ is the partial pressure of the ammonia in the air phase [atm] and $\mathrm{Cw}$ is concentration of the ammonia in the water [mole.m-3]. If the ammonia in gas phase is assumed as an ideal gas and the concentration of the gas is expressed in unit of concentration [mole.m-3] instead of pressure, equation (3) can be expressed as equation (4) :

$$
K_{H}^{\prime}=\frac{C_{a}}{C_{w}},
$$

Where $\mathrm{Ca}$ is concentration of ammonia in the air and $\mathrm{K}$ ' $\mathrm{H}$ is dimensionless Henry's law constants. Based on the reaction equation (2) we can obtain the equilibrium equation of the ammonia and ammonium in aqueous phase, as for being expressed at equation (5):

$K_{b}=\frac{\left[\mathrm{NH}_{4}^{+}\right]\left[\mathrm{OH}^{-}\right]}{\left[\mathrm{NH}_{3}\right]}$

By increasing $\mathrm{pH}$, the equilibrium of system will shift toward to the left. It's means that by increasing $\mathrm{pH}$, amount of ammonia phase is dominant then ammonium phase, so it will increase amount of ammonia in gas phase until certain equilibrium achieved. Ammonia gas released into the air will be detected by sensor and read by microcontroller as voltage number which relates to the analog ammonia/ammonium concentration in the water. Simple design of analyzer compartment was shown in (Figure 1).

In this research, standard solution of ammonium chloride in various concentrations is used for ammonia analyzer compartment adjustment. By graphed relation of the ammonium chloride standard solution to voltage, number resulted can be obtained an equation which expressed analog ammonia concentration in the water. 
The result of an instrument adjustment test was shown in (Figure 2).

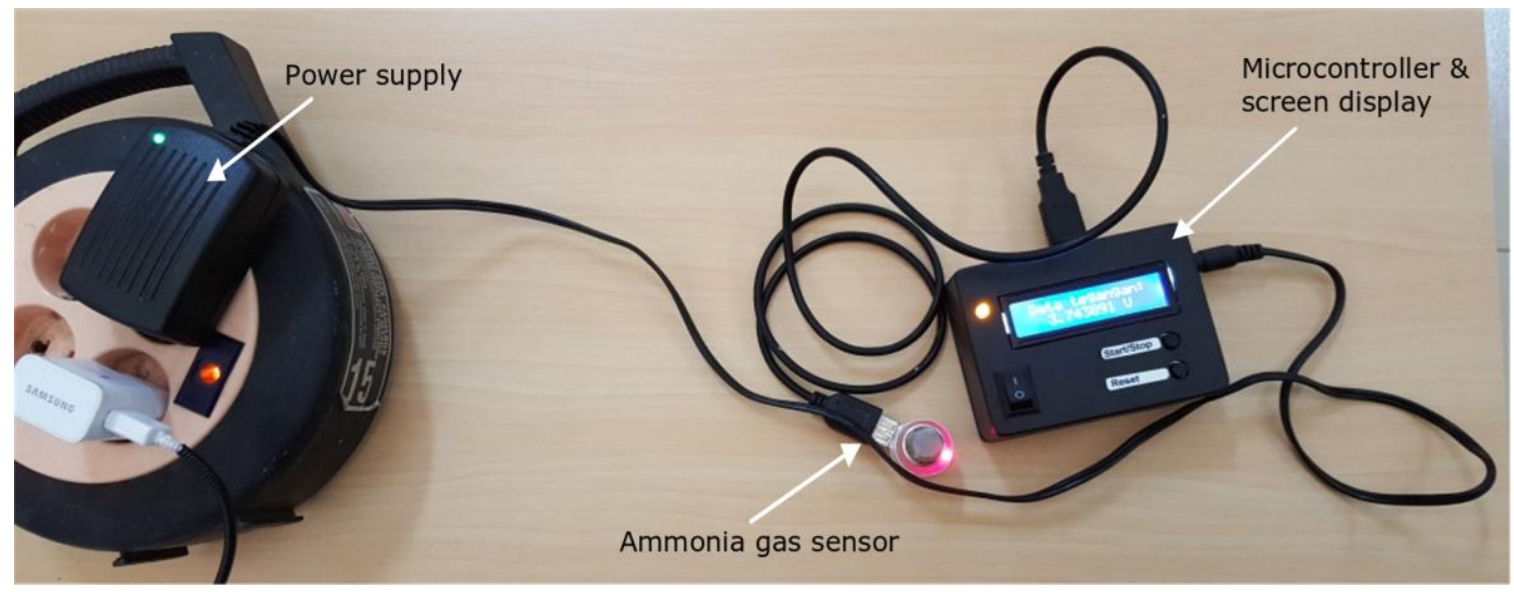

Figure 1. Analyzer compartment of AnCerD Instrument.

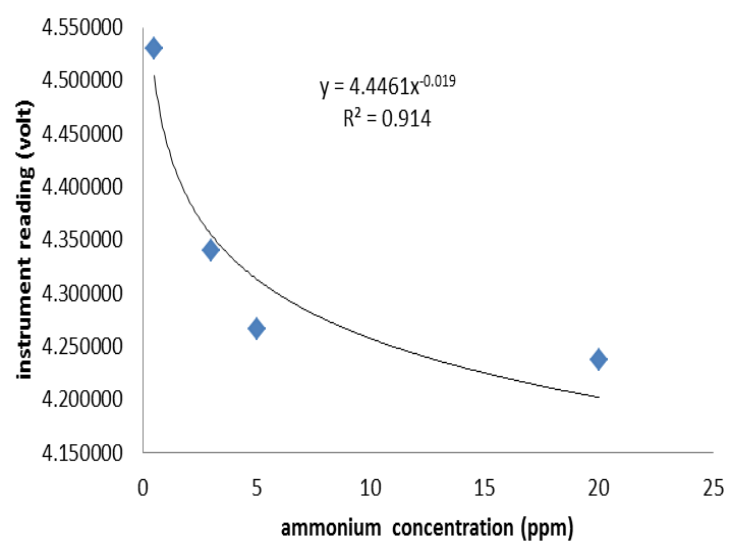

Figure 2. Graph function of voltage number to ammonium concentration.

\section{Adjustment test of Converter Compartment}

Converter compartment adjustment carried out in various selected time of electrolysis. Artificial sample used in this stage is ammonium chloride $100 \mathrm{ppm}$ and electrolyzed at selected time i.e. 20, 40, 60, 120, and 180 seconds respectively. Result of this test shows that ammonium remains in water decrease with the length of electrolysis time (Figure 3).

\section{Performance Test of the Instrument for Real Sample}

\section{Comparative Test}

Comparative test was carried out by comparing measurement result of analyzer compartment of AnCerDD instrument to the ammonia monitoring result from PT IBD on March 2015. Characteristic of PT IBD's wastewater is shown in (Table 1). In this case, we compared result of AnCerDD Method and spectroscopic method of Indonesian National Standard (SNI 06-6989.30-2005). P value resulted for onesample T-test is $0.462(\mathrm{P}>0.05)$. Its mean that no significant difference result between AnCerD Method and spectroscopic method (see Table 2 and Table 3 ).
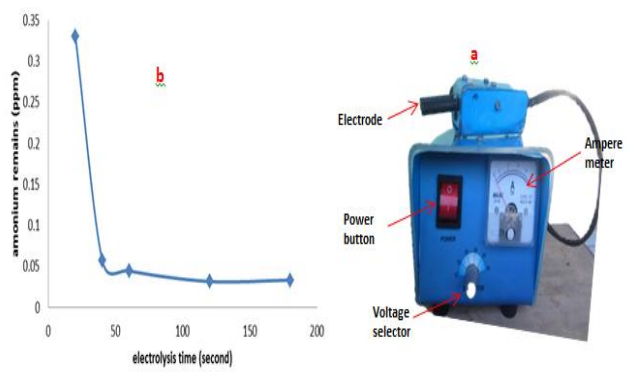

Figure 3. Converter compartment of AnCerD (a) and result of adjustment test (b).

Table 1. Characteristic of PT. IBD's waste water.

\begin{tabular}{lll}
\hline $\begin{array}{l}\text { Parameter } \\
\text { Wastewater }\end{array}$ & Quantity & Unit \\
\hline $\mathrm{pH}$ & 7.5 & - \\
$\mathrm{BOD}$ & & $\mathrm{mg} / \mathrm{l}$ \\
$\mathrm{COD}$ & 25.05 & $\mathrm{mg} / \mathrm{l}$ \\
$\mathrm{TSS}$ & 447.15 & $\mathrm{mg} / \mathrm{l}$ \\
$\mathrm{NH}_{3}-\mathrm{N}$ & 130 & $\mathrm{mg} / \mathrm{l}$ \\
$\mathrm{NO}_{3}-\mathrm{N}$ & 0.210 & $\mathrm{mg} / \mathrm{l}$ \\
$\mathrm{NO}_{2}-\mathrm{N}$ & 2.011 & $\mathrm{mg} / \mathrm{l}$ \\
$\mathrm{H}_{2} \mathrm{~S}$ & 1.86 & $\mathrm{mg} / \mathrm{l}$ \\
$\mathrm{PO}_{4}$ & $<0.001$ & $\mathrm{mg} / \mathrm{l}$ \\
\hline
\end{tabular}

Table 2. Comparative test result.

\begin{tabular}{lll}
\hline Sample & $\begin{array}{l}\text { AnCerD } \\
\text { Method }\end{array}$ & $\begin{array}{l}\text { Spectroscopic Method } \\
\text { (SNI 06-6989.30-2005). }\end{array}$ \\
\hline $\begin{array}{l}\text { First Pond of } \\
\text { Outlet canal }\end{array}$ & $0.1834 \mathrm{mg} / 1$ & $0.210 \mathrm{mg} / \mathrm{l}$ \\
& $0.2356 \mathrm{mg} / 1$ & \\
& $0.3126 \mathrm{mg} / 1$ & \\
\hline
\end{tabular}


Table 3. Result of one-sample T-test between AnCerDD method and spectroscopic method

Results for: One-Sample T: ANCERDD-SPECTROSCOPIC METHOD

(Test of $\mu=0.21$ vs $\neq 0.21$ )

\begin{tabular}{llllllll}
\hline Variable & $\mathrm{N}$ & Mean & StDev & SE Mean & 95\% CI & T & P \\
\hline ANCERDD & 3 & 0.2439 & 0.0650 & 0.0375 & $(0.0824,0.4053)$ & 0.90 & 0.462 \\
\hline
\end{tabular}

\section{Ammonia Conversion Capability Test}

In this test, targeted ammonia conversion capability of AnCerD instrument for real sample (PT IBD's wastewater) was $95 \%$. Ammonia conversion capability test had been done by electrolysis method on 12 volts and 3-ampere direct current in various time of electrolysis. Result of ammonia conversion capability test shown by Table 4. Based on (Table 4), the percentage of converted ammonia is increased as a long time of electrolysis.

Table 4. Ammonia conversion capability test of AnCerD instrument.

\begin{tabular}{|c|c|c|c|c|}
\hline $\begin{array}{l}\text { Time of Electrolysis } \\
\text { (Minutes) }\end{array}$ & $\begin{array}{l}\text { Initial } \\
\text { Concentration of } \\
\text { Ammonia (mg/l) }\end{array}$ & $\begin{array}{l}\text { Concentration of } \\
\text { Ammonia After } \\
\text { Treatment (mg/l) }\end{array}$ & $\begin{array}{l}\text { Converted Ammonia } \\
\text { (mg/l) }\end{array}$ & $\begin{array}{l}\text { Percentage of Converted } \\
\text { Ammonia }(\%)\end{array}$ \\
\hline 10 & 0.2356 & 0.0144 & 0.2212 & 93.89 \\
\hline 12 & 0.2356 & 0.0127 & 0.2229 & 94.61 \\
\hline 14 & 0.2356 & 0.0105 & 0.2251 & 95.56 \\
\hline 16 & 0.2356 & 0.0103 & 0.2253 & 95.64 \\
\hline 18 & 0.2356 & 0.0112 & 0.2244 & 95.23 \\
\hline
\end{tabular}

\section{CONCLUSIONS}

Based on data and discussion above we could conclude that AnCerD instrument shown good performance, where no significant different result between analyzer compartment measurement and spectroscopic method of SNI 06-6989.30-2005. Good performance was also shown by converter compartment testing result where the ammonia conversion efficiency achieved more than $95 \%$ after 14 minutes.

\section{ACKNOWLEDGMENTS}

I have great pleasure in expressing my deep sense of gratitude to LP2M UIN Sunan Kalijaga and the Management of PT. Indokor Bangun Desa Yogyakarta for support, funding, and encouragement to publish this research.

\section{REFERENCES}

Brett, C. M. A. and Brett, A. M. O., 1993, Electrochemistry: Principles, Methods, and Applications, Oxford University Press Inc., New York, pp. 326-328.
Chang, Raymond. 2005. Kimia Dasar Edisi Ketiga Jilid 2. Jakarta: Erlangga.

DaeGun Kim, et al. 2013. Agro Industrial Wastewater Treatment by Electrolysis Technology. International Journal Electrochem. Sci., 8 (2013) 9835-9850.

Darmono, Mulyoko. Efisiensi Arus Elektrolisis Pada Sel Elektrolisis Platina-Platina Asam Nitrat. Serpong: Pusat Pengembangan Pengelolaan Limbah Radioaktif-BATAN.

Kim, K. W., Kim, Y. J., Kim, I. T., Park, G., Lee, E. H., 2006, Electrochemical Conversion Characteristics of Ammonia to Nitrogen, Water Research, 40, 1431-144.

Riwayati, Indah dan Ratnawati, 2010, Penurunan Kandungan Ammonia Dalam Air Dengan Teknik Elektrolisis, Jurnal Seminar Rekayasa Kimia dan Proses, page 5.

Sutopo, H.B. 2002. Metode Penelitian Kualitatif. Surakarta: UNS Press.

Wang, Yaning, et al. 2012. Efficient Electrochemical Removal of Ammonia with Various Cathodes and Ti/RuO2-Pt Anode. Open Journal of Applied Sciences, 2012, 2, 241-247.

Yan, L., Liang, L., Goel, R., 2009, Kinetic Study of Electrolytic Ammonia Removal Using Ti/IrO2 as Anoda Under Different Experimental Conditions, Journal of Hazardous Materials, 161, 1010-1016.

Yue, Lin, et al., 2013, Studies On The Electrochemical Degradation of Acid Orange II Wastewater with Cathodes Modified by Quinones, J. Ind. Eng. Chem., http://dx.doi.org/10.1016/j.jiec.2013.06.003

Zoski, G. C., 2007, Handbook of Electrochemistry, First edition, Elsevier, Amsterdam, pp. 08-14. 